\title{
Hypersensitivity to Aspirin and other NSAIDs: Diagnostic Approach in Patients with Chronic Rhinosinusitis
}

\author{
Joanna Makowska $^{1}$ • Anna Lewandowska-Polak ${ }^{1} \cdot$ Marek L. Kowalski $^{1}$ \\ Published online: 7 July 2015 \\ (C) The Author(s) 2015. This article is published with open access at Springerlink.com
}

\begin{abstract}
Hypersensitivity to nonsteroidal anti-inflammatory drugs (NSAIDs) associated with chronic rhinosinusitis (CRS) and/or asthma comprises a distinct clinical syndrome referred to as NSAIDs exacerbated respiratory disease (NERD). Patients with NERD tend to have more severe course of both upper (CRS and nasal polyps) and lower airway (asthma) diseases and are usually recalcitrant to conventional treatment modalities. Diagnosing and phenotyping of patients with NERD are critical for prevention of drug-induced adverse reactions and open novel options for management of underlying chronic airway inflammatory diseases. Diagnosis of NERD is based on detailed clinical history confirmed by challenge with aspirin, but new diagnostic approaches are currently being developed. This review article focuses on the diagnostic approach to a patient with CRS and hypersensitivity to NSAIDs, emphasizing the importance of diagnosis for proper patient's management.
\end{abstract}

Keywords Chronic rhinosinusitis · Aspirin · NERD · Drug challenges

This article is part of the Topical Collection on Rhinosinusitis

Marek L. Kowalski

marek.kowalski@.csk.umed.lodz.pl

1 Department of Immunology, Rheumatology and Allergy, Healthy Ageing Research Center, Medical University of Łódź, 251 Pomorska Str., 92-213 Łódź, Poland

\section{Introduction}

Acute forms of hypersensitivity to aspirin and other nonsteroidal anti-inflammatory drugs (NSAIDs) are among the most common drug hypersensitivities, may affect $1-2 \%$ of general population and manifest with the whole variety of symptoms involving skin (rush, urticaria, and angioedema), respiratory tract (rhinorrhea, nasal congestion, and bronchospasm), and in some patients systemic anaphylaxis may develop [1, $\bullet$ ]. Among patients with asthma and/or chronic rhinosinusitis (CRS) with nasal polyps, the prevalence of NSAIDs hypersensitivity is significantly higher reaching $26 \%$ and is associated with severe eosinophilic hyperplastic inflammation of both upper and lower airway mucosa [3]. This syndrome has been previously referred to as "aspirin triad", and more recently, the term NSAIDs-exacerbated respiratory disease (NERD) has been used, reflecting the presence of chronic inflammation of upper and lower mucosa of patients with this type of drug hypersensitivity $[4 \cdot]$.

\section{Chronic Rhinosinusitis and NSAID-Hypersensitivity}

History of hypersensitivity to aspirin and other NSAIDs is a hallmark of particularly persistent and resistant to treatment form of rhinosinusitis, associated with recurrent nasal polyposis [5-8] (Fig. 1). Although NSAIDs can evoke hypersensitivity reactions in patients with CRS, but without lower airway involvement, the majority of patients would suffer from chronic bronchial asthma. The higher than usual severity of the upper airway disease in NERD patients is reflected by recurrence of nasal polyps and frequent need for sinus surgery $[7,9]$. As it has been documented with computer tomography in these patients, mucosal hypertrophy usually involves all sinuses and nasal passages and has significantly higher extent 
Fig. 1 Clinical characteristics of NSAID exacerbated respiratory disease (modified from M.L .Kowalski, S. Bavbek, Aspirin Exacerbated Respiratory Disease, in Global Atlas of Asthma, Eds. C.A. Akdis, I. Agache, pp 92-94, EAACI 2013)

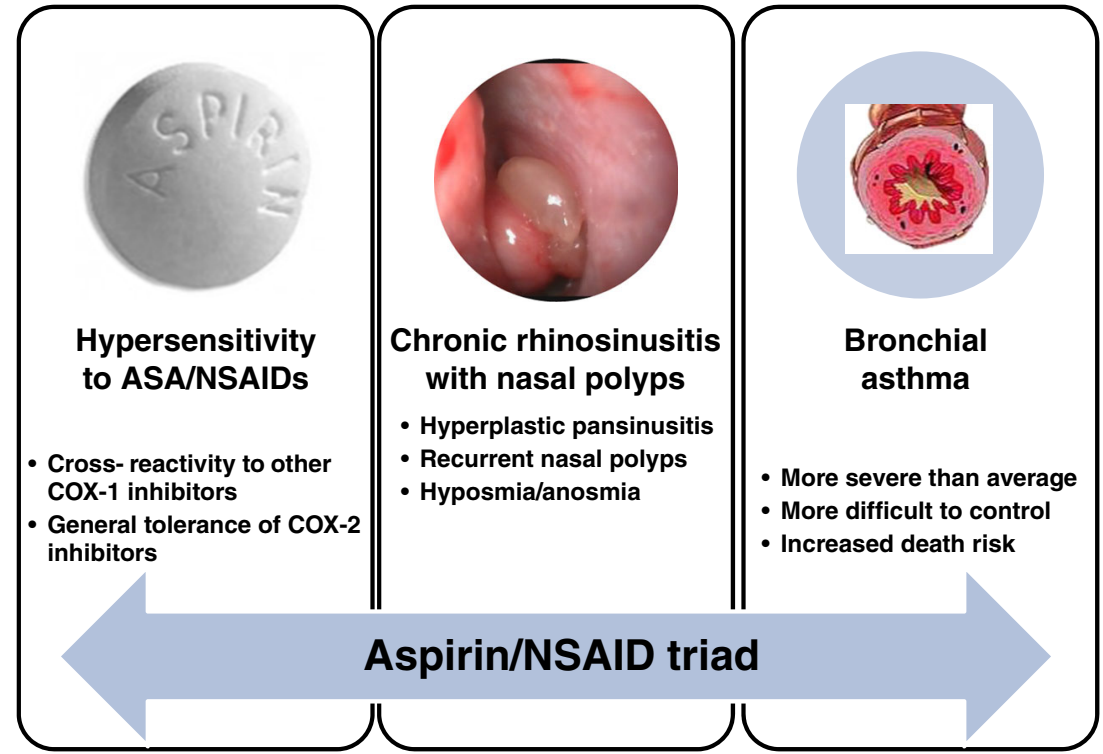

and thickness compared to CRS in aspirin tolerant patients [10].

\section{Pathophysiology of NSAIDs-Exacerbated Respiratory Disease}

Pathophysiology of NERD should be considered as a coincidence of two possibly distinctive, but to some extent overlapping mechanism: one being responsible for NSAIDs-induced acute hypersensitivity reaction and the other determining the presence of chronic eosinophilic mucosal inflammation in the airways, and resulting in persistent symptoms of rhinosinusitis, nasal polyps, and asthma [11].

\section{Mechanism of Acute NSAIDs-Induced Hypersensitivity Reactions}

Hypersensitivity reaction induced by aspirin and NSAIDs is not immunological phenomenon, but results from inhibition of cyclooxygenase- 1 and prostaglandin synthesis, which leads to activation of inflammatory cells (mostly mast cells and eosinophils, but possibly platelets) with subsequent release of leukotrienes and other inflammatory mediators in the mucosa [12-14]. These mediators are responsible for clinical manifestation of acute hypersensitivity reaction: bronchial obstruction, rhinorrhea, and nasal congestion. Avoiding aspirin and other NSAIDs with strong anti-COX-1 activity or using selective COX-2 inhibitors would prevent development of acute reactions. Although the causal relationship between inhibition of COX-1 by NSAIDs and development of symptoms has been well documented, the mechanism of inflammatory cells activation by NSAIDs is speculative and potentially may involve increased susceptibility of cyclooxygenase- 1 to inhibition by NSAIDs, intrinsic deficiency of prostaglandin $E_{2}[15 \bullet]$, and/or decreased function of prostaglandin $E_{2}[16$, 17]. Cysteinyl leukotrienes $\left(\mathrm{LTC}_{4} / \mathrm{D}_{4}\right)$ are consistently increased after positive aspirin challenge in lower and upper airways, and leukotriene $\mathrm{LT}_{1}$ receptor antagonists partially prevent NSAID-induced reaction suggesting a key role of leukotrienes in the pathophysiology of acute NSAIDs-induced reaction [18]. The role of other arachidonic acid metabolites as prostaglandin $\mathrm{D}_{2}\left(\mathrm{PGD}_{2}\right)$ or 15-hydroxyeicosatetraenoic acid (15-HETE) is also feasible [19-22, 23•].

\section{Pathomechanism of Chronic Eosinophilic Airway Inflammation}

Increased tissue eosinophilia and release of eosinophil cationic protein (ECP) in nasal polyps from NERD patients have been linked to distinctive profile of cytokine expression and upregulation of cytokines related to eosinophil activation and survival (e.g., IL-5, GM-CSF, RANTES, and eotaxin) [16, 24, 25 ] and is associated with differential expression of remodeling markers [26]. It has been recently documented that higher INF- $\gamma$ levels are produced by eosinophils in nasal polyps tissue from NERD patients and INF- $\gamma$ promoted maturation of eosinophil progenitors, results in enhanced expression of eosinophil-associated genes related to the leukotriene pathways (e.g., CysLT 1 receptor or LTC4 synthase) [27].

Mast cells seem to be important component of the upper and lower airway inflammation in NSAIDs-hypersensitive patients [28, 29], since serum baseline levels of mast cell derived mediators tryptase and stable $\mathrm{PGD}_{2}$ metabolite are elevated [30]. In the nasal polyp tissue, the density of mast cells (and stem cell factor) was correlated with the number of polypectomies, implicating an important role for these cells in the pathogenesis of nasal polyposis [28]. 
Several abnormalities related to both cyclooxygenase and lipoxygenase pathways of arachidonic acid (AA) metabolism have been documented in the upper airway mucosa of NERD patients [31, 32]. Decreased expression of COX-2 mRNA leading to lower generation of $\mathrm{PGE}_{2}$ by nasal polyps, nasal polyp epithelial cells, and bronchial fibroblasts was reported [33-36] which together with reduced expression of prostaglandin $\mathrm{EP}_{2}$ receptors could result in impaired anti-inflammatory response [37, 38]. An increased generation of cysteinyl leukotrienes, overexpression of enzymes involved in production of leukotrienes (5-lipoxygenase and leukotriene $\mathrm{C} 4$ synthase) together with increased expression of leukotriene type $1\left(\mathrm{LT}_{1}\right)$ receptors in the nasal mucosa of NERD patients may result in local hyperresponsiveness to leukotrienes in this subpopulation of patients [39, 40]. On the other hand, chronic treatment with $\mathrm{LT}_{1}$ receptor antagonist is not more effective in relieving nasal and bronchial symptoms or reducing polyp size in NERD as compared to NSAID-tolerant patients, thus other factors had to be involved in the persistence of inflammation in these patients $[41,42]$. A decreased production of the anti-inflammatory lipoxin $\mathrm{A}_{4}$ in nasal polyp tissue and peripheral blood leukocytes from NSAID-sensitive patients further suggests an important role for dysregulation of AA metabolism [39, 40]. However, in patients with NERD eosinophilic inflammation in the lower and upper airways may precede, even several years, development of hypersensitivity to aspirin and persists even if they avoid intake of aspirin or other NSAIDs, pointing at involvement of other factors and mechanism, beyond AA metabolism [43].
The role for infections, both viral and bacterial, has been postulated, but not convincingly documented [44]. Higher concentrations of IgE-antibodies to Staphylococcal aureus enterotoxins (SAEs) in nasal polyps and serum have been associated with the presence of NSAIDs hypersensitivity, suggesting that Staphylococcus aureus superantigens may trigger T cell-mediated inflammatory reaction and/or exert direct effects on eosinophil proliferation and survival in the airway mucosa of NERD patients [45, 46]. Genetic background may be also important factor determining different pathophysiology and higher severity of CRS in NSAIDs hypersensitive patients [47].

\section{Diagnostic Approach to a Patient with NERD}

Patients suspected to have NERD require not only documentation of an acute hypersensitivity reaction (by history and/or aspirin challenge) but also detailed evaluation of the extent of underlying diseases of the upper and lower airways (Fig. 2).

\section{Diagnosis of Chronic Rhinosinusitis}

Diagnosis of CRS is based on history of presence of typical sinonasal symptoms (nasal blockage or obstruction, nasal discharge, and olfactory dysfunction) for more than 12 weeks and should be supported by nasal endoscopy and computed tomography (CT) scan of paranasal sinuses [48, 49]. Patients with NSAIDs hypersensitivity on average would have a history of long-lasting CRS with higher than average severity
Fig. 2 Diagnostic steps in a patient with chronic rhinosinusitis and suspected hypersensitivity to NSAIDs

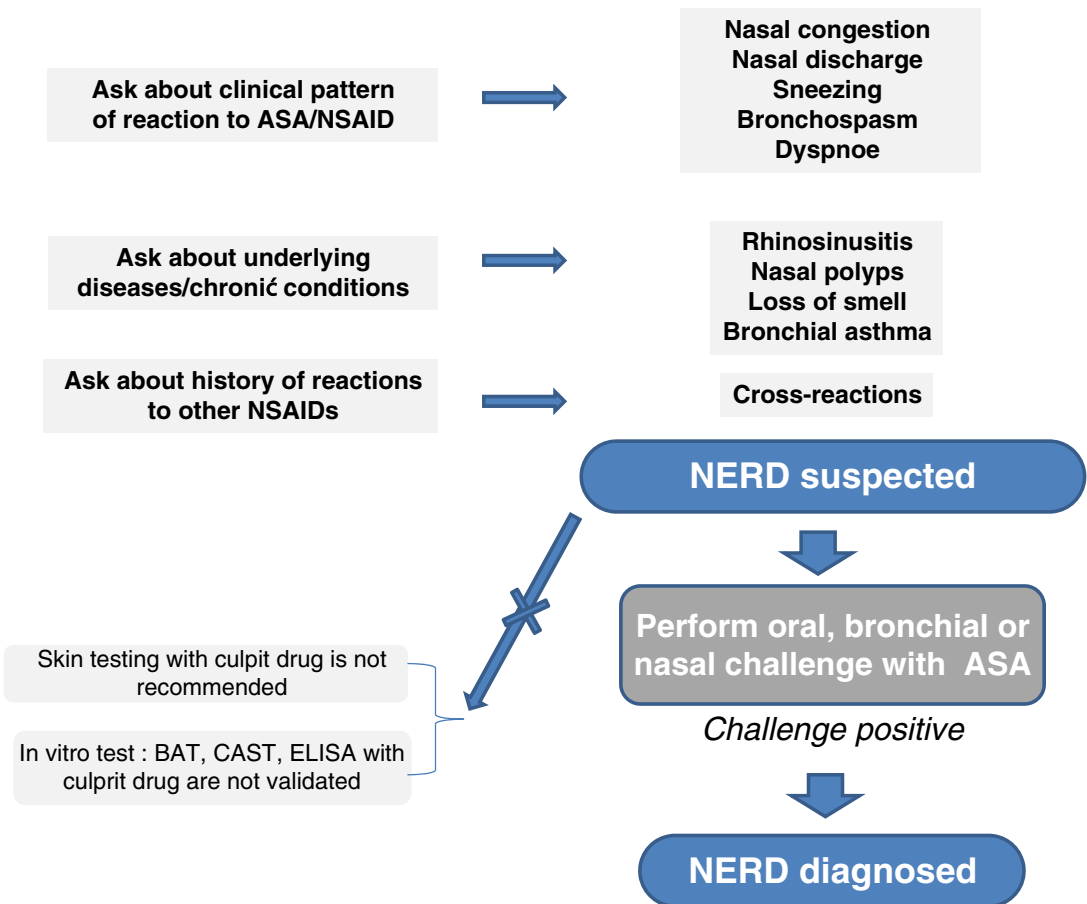


and resistance to both pharmacological and surgical treatment [7]. Reduced or lost sense of smell which commonly occurs in CRS patients with nasal polyps with and without NSAIDs hypersensitivity may be a leading symptom in NERD patients [50].

A distinctive feature of CRS in NERD patients is rapid recurrence of nasal polyps and mucosal hypertrophy following standard polypectomy or even functional endoscopic sinus surgery (FESS) [9]. It has been documented that patients with NERD have ten times increased risk of polyp recurrence after FESS as compared to aspirin tolerant patients [48, 49].

On CT scans, almost all patients with NERD have mucosal hypertrophy, and its extent is significantly higher in NSAIDshypersensitive as compared to NSAIDs-tolerant patients [10]. The intensity of sinus hypertrophy assessed by CT may predicts probability of NERD, and sinus CT score below 12 would support the likelihood of aspirin tolerance in a patients with unclear history of hypersensitivity reaction to aspirin and NSAIDs [48].

\section{Comorbidities}

Only a tiny fraction of patients with CRS and nasal polyps is reacting to aspirin and NSAIDs only with upper respiratory symptoms, and even those with time will present lower symptoms after NSAIDs. Large majority will have a history of lower airway symptoms (dyspnea and wheezing) after aspirin intake, and these patients usually suffer from chronic bronchial asthma [51]. Patients with NERD tend to suffer from more severe form of the disease which is associated with less control and with increased risk of life-threatening asthma attacks $[8,2 \cdot]$.

All patients with nasal polyps and NSAIDs hypersensitivity should also undergo full allergic evaluation since majority (50-70\%) may have allergic sensitizations to inhalant allergens; thus, atopy should not exclude the suspicion of NSAIDs hypersensitivity if other risk factors (e.g., severe asthma or nasal polyposis) exist [52-55]. The presence of atopy was suggested to be a risk factor for aspirin hypersensitivity among asthmatics patients challenged with oral aspirin, thus atopic sensitization to inhalant allergens may be important mechanism contributing to the pathogenesis of the airway inflammation in a patient with NERD [53].

\section{Diagnosis of NSAIDs Hypersensitivity}

\section{History and Physical Examination}

Patient with NERD would present a history of acute rhinorrhea and nasal congestion usually accompanied by bronchial symptoms (dyspnea), which develop usually within 1-2 $\mathrm{h}$ after ingestion of aspirin or other NSAIDs (e.g., naproxen, diclofenac, or ketoprofen) with known COX-1 inhibitory capacity. On the other hand patient usually reports, that some NSAIDs, which are weak inhibitors of prostaglandin synthesis, like paracetamol and preferential COX-2 inhibitors, are well tolerated.

Approximately $10 \%$ of patients with NERD may simultaneously manifest non-respiratory, usually cutaneous symptoms (urticaria and/or angioedema) after intake of aspirin. Thus, a patient with CRS and history of adverse reaction to aspirin or other NSAIDs should be fully evaluated with respect to potential type of hypersensitivity which may involve in addition lower respiratory and cutaneous symptoms [2•].

\section{Provocations Tests}

Although in clinical practice diagnosis of drug hypersensitivity is usually based on history of adverse reaction associated with the culprit drug, such history may not be reliable leading to either under diagnosis or over diagnosis of drug hypersensitivity [56•]. In study of Dursun et al. [57], history of NSAIDs -induced reactions could not be confirmed with oral challenge in $16 \%$ of patients with NERD, and only $43 \%$ patients with chronic sinusitis, nasal polyps, and asthma who were avoiding aspirin or NSAIDs had a positive oral aspirin provocation. Thus, oral aspirin challenge is recommended to confirm the diagnosis of NSAIDs hypersensitivity regardless of the clinical manifestation, while nasal or bronchial provocation with lysine-ASA may be alternatively used in patients with respiratory symptoms [58, 59].

Advantages and limitations of various provocation methods are summarized in Fig. 3.

\section{Oral Provocation Test}

Several protocols for oral aspirin provocation varying in recommended aspirin dose increments and intervals between up dosing are available, and recently, EAACI/GA ${ }_{2} \mathrm{LEN}$ expert panel proposed a protocol which merges experience of several groups [58, 60-62].

Oral challenge should be performed in a setting with immediate access to emergency equipment, and service after all contraindications were considered [63]. In patients with asthma, the disease should be well controlled and FEV ${ }_{1}$ should exceed $70 \%$ of predicted values. On the first day, in order to establish baseline variability, placebo capsules are administered every $1.5-2 \mathrm{~h}$ and $\mathrm{FEV}_{1}$ is measured every $30 \mathrm{~min}$ (respiratory function is monitored even if in patients without history of asthma). On the second day, patient receives initially $10-30 \mathrm{mg}$ of aspirin and the dose is doubled in 1.5 to $3 \mathrm{~h}$ intervals until positive reaction occurs. In a patient with rhinosinusitis, without bronchial asthma, development of upper respiratory symptoms (nasal congestion and rhinorrhea) may be diagnostic. Acoustic rhinomanometry can be used to 
Fig. 3 Advantages and limitations of oral, intranasal, and bronchial route of aspirin provocation in patients with NERD (modified from M.L. Kowalski In vivo diagnosis of NSAIDs hypersensitivity, in Global Atlas of Allergy, Eds C. A. Akdis I. Agache, pp. 158-160, EAACI, 2014)

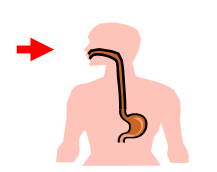

\begin{tabular}{|l|l|}
\hline \multicolumn{1}{|c|}{ Advantages } & \multicolumn{1}{c}{ Limitations } \\
\hline Gold standard ( reliable ) & Risk of severe reaction \\
\hline $\begin{array}{l}\text { Useful in patients with nasal } \\
\text { and/or bronchial symptoms }\end{array}$ & Time-consuming \\
\hline
\end{tabular}

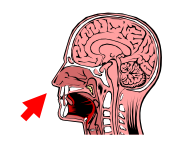

Reliable in patients with CRS

Not possible in patients with nasal obstruction

Safe in patients with concomitant severe/ unstable asthma

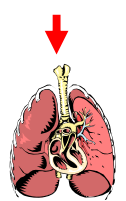

\begin{tabular}{|l|l|}
\hline Short duration $(<4 \mathrm{~h})$ & $\begin{array}{l}\text { Only in patients with } \\
\text { bronchial/nasal reaction }\end{array}$ \\
\hline Reaction easily reversible & Requires special equipment \\
\hline
\end{tabular}

document nasal obstruction during the challenge. In a patient with asthma, the reaction is considered positive if at least $20 \%$ fall in $\mathrm{FEV}_{1}$ occurs, which may be accompanied nasal, ocular, cutaneous, or gastrointestinal symptoms. If the final dose $312 \mathrm{mg}$ of aspirin (corresponding to $500 \mathrm{mg}$ of cumulative dose) is ingested and well tolerated the patient is considered to be aspirin tolerant [63].

The negative challenge result should be analyzed with caution since it may reflect either development of "silent desensitization" during the challenge procedure or blocking effects of medications used to control chronic inflammatory disease $[64,65]$. For example, the use of antihistamines may significantly decrease development not only of cutaneous but also respiratory symptoms. On the other hand, discontinuing controller medications before aspirin challenge in patients with suspected NSAIDs hypersensitivity is not recommended since it may increase the risk of severe reactions $[66,67]$.

Since diagnostic oral challenge tests are time-consuming procedure, requiring well-experienced personnel and may be associated with a risk of severe systemic reaction, oral provocation test may be substituted with inhaled or intranasal aspirin challenges [58, 68].

\section{Nasal Provocation Test}

Intranasal provocation with lysine aspirin (a soluble form of ASA) is a good alternative for oral challenge since it is rapid, safe, and can be performed in an outpatients setting and even in asthmatic patients with low pulmonary function not suitable for bronchial provocation [5, 68-72]. However, this route of challenge cannot be used in patients with significant nasal obstruction, turbulent nasal flow, or unspecific nasal responsiveness [68]. Table 1 presents studies reporting diagnostic effectiveness of intranasal challenges with aspirin. The sensitivity of aspirin nasal challenge test ranges from $38 \%$ in study of Patriarca [72] to $87 \%$ in study of Milewski [68] and specificity from 84 [71] to $96 \%$ [68]. The study of Miller [73] in which higher doses of lysine aspirin showed similar sensitivity $88 \%$. The nasal provocation test seems to be a safe alternative for oral and bronchial challenge in patients with severe asthma as in most patient intranasal delivery of aspirin did not evoke severe bronchoconstriction [68, 74•, 75•]. However, in occasional, patients application of lysine aspirin by atomizer or using of higher doses of aspirin can lead to bronchial symptoms with significant drop in $\mathrm{FEV}_{1}>30 \%$, which is pointing at necessity of respiratory function monitoring by spirometry during nasal provocation with aspirin [70, 73].

Lysine aspirin can be substituted with ketorolac another NSAID, which in a soluble form is more easily available in some countries [76]. Reproducibility of nasal challenges in which combination of acoustic rhinomanometry and symptoms scores is used to assess the results $[73,74 \cdot, 77]$ is very high reaching $98 \%$ [73]; however, good reproducibility of peak nasal inspiratory flow (PNIF) measurements have been also reported [78].

\section{Bronchial Aspirin Provocation}

Bronchial provocation with lysine aspirin is reliable alternative for oral provocation with aspirin in patients with diagnosis of asthma or with history of lower respiratory symptoms after NSAIDs [58, 63]. However, in patients with CRS without asthma or with history of only upper airway symptoms after NSAID, oral provocation cannot be substituted with inhalation challenge. 


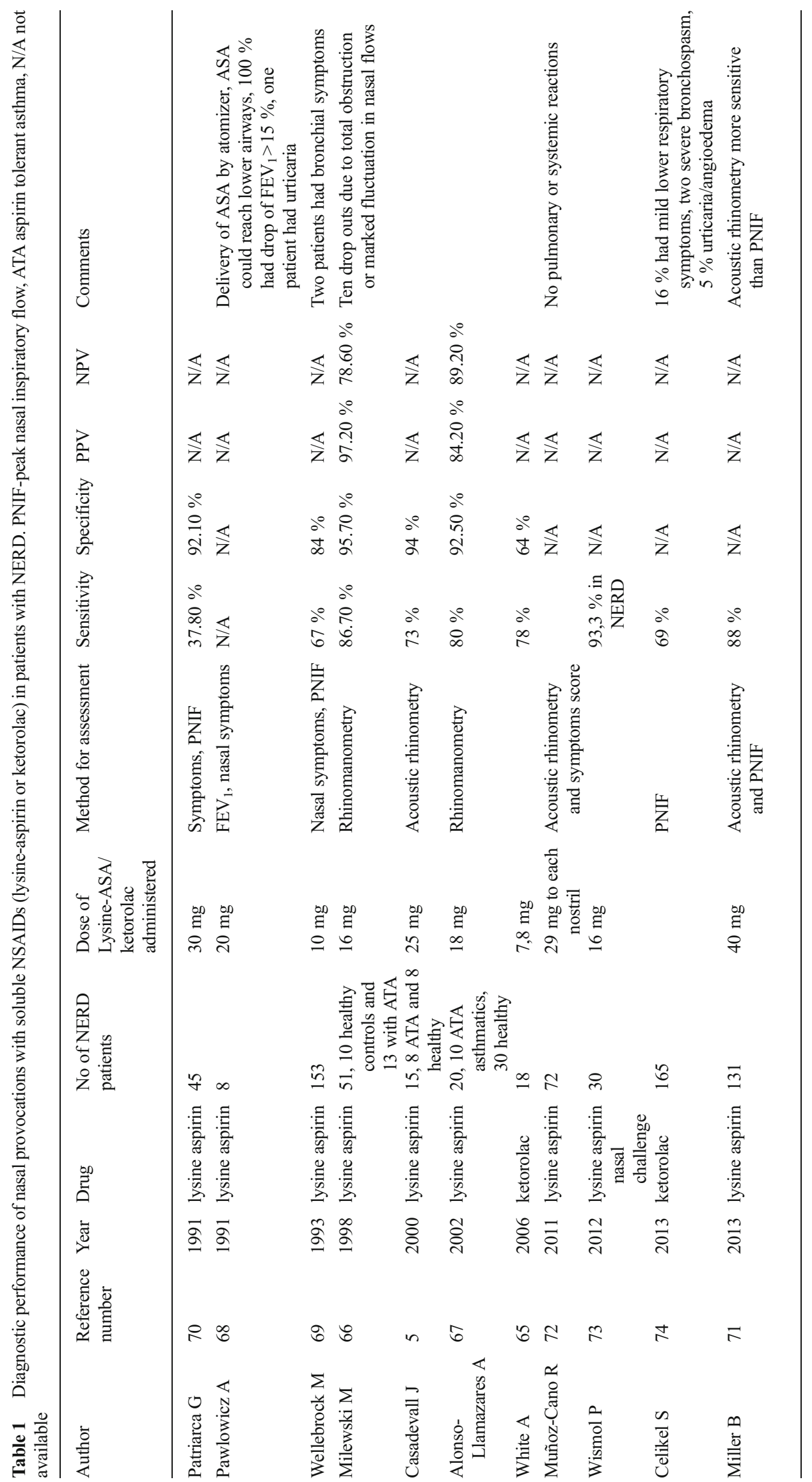




\section{In Vitro Tests for Diagnosis of NSAIDs Hypersensitivity}

Although several tests based on measuring of in vitro activation of peripheral blood leukocytes have been proposed, no in vitro test can match provocation challenges with respect to sensitivity or specificity (Table 2).

Sulfidoleukotrienes Release Assay Aspirin-triggered release of LTC4 from peripheral blood leukocytes (CAST-ELISA) has been tested in several studies [79-81], in highly selected population, but has not been validated for routine use [82-84].

Basophil Activation Tests (BAT) BAT was tested in populations of patients with both respiratory and/or cutaneous type of hypersensitivity to different NSAIDs with not well characterized, control populations, and its utility for diagnosis of respiratory type of aspirin sensitivity has not been sufficiently documented [75•, 85-87].

15-HETE generation assay (ASPITest) is based on observation that aspirin could more readily trigger in vitro generation of 15-hydroxyicosatetraenoic acid (15HETE) from nasal polyp epithelial cells and peripheral blood leukocytes from ASA-hypersensitive patients, as compared to ASA-tolerant asthmatics or healthy subjects, and measurement of 15-HETE release from PBLs has been proposed to be used to confirm history of aspirin hypersensitivity in patients with NERD [19, 20, 88]. The sensitivity of aspirin-triggered 15-HETE release (ASPITest) tested in highly selected population of patients with NERD demonstrated $82 \%$ sensitivity and $83 \%$ specificity [88]. However, more recent studies including more heterogeneous populations of patients with asthma and/or using isolated eosinophils demonstrated non-specific release of 15-HETE form PBLs and could not reproduce diagnostic performance of 15HETE measurement for NERD [89, 90]. Further studies are required to refine the methodology and to assess diagnostic effectiveness of this method.

\section{New Diagnostic Approaches}

Several biochemical abnormalities related to arachidonic acid metabolism can be detected in easily available biological materials like blood, urine, or exhaled air of patients with NERD. However, diagnostic value of measurement of AA metabolism products to predict or confirm NSAIDs hypersensitivity has not been assessed.

$\mathbf{L T E}_{\mathbf{4}}$ Urinary Levels Increased basal levels of leukotriene $\mathrm{E}_{4}$ in urine have been consistently reported in NERD patients, but a significant overlap with non-sensitive

Table 2 Performance of in vitro test in the diagosis of NERD

\begin{tabular}{|c|c|c|c|c|c|c|c|c|}
\hline First author & Year & Test & No of patients & Cells/stimulus & Sensitivity & Specificity & PPV & NPV \\
\hline Kowalski ML & 2003 & AspiTest (15-HETE release) & 16 & Leukocytes/ $200 \mathrm{uM}$ of ASA & - & - & - & - \\
\hline Kowalski ML & 2005 & AspiTest (15-HETE release) & 43 & Leukocytes/ $200 \mathrm{uM}$ of ASA & $82 \%$ & $83 \%$ & 0.79 & 0.89 \\
\hline Kosec P & 2011 & AspiTest (15-HETE release) & 26 & leukocytes / 500uM of ASA & $63 \%$ & $50 \%$ & - & - \\
\hline James A & 2013 & $\begin{array}{l}\text { 15-HETE release from } \\
\text { eosinophils upon } \\
\text { stimulation with ASA }\end{array}$ & 7 & Eosinophils / 200uM of ASA & - & - & - & - \\
\hline Lebel B & 2001 & CAST & 55 & Leukocytes/beta-lactam, ASA, paracetamol & & & & \\
\hline Bavbek S & 2009 & CAST & 30 & Basophils/ASA, diclophenac & $25 \%$ & $92.30 \%$ & 0.29 & 0.91 \\
\hline de Weck & 2009 & $\mathrm{CAST}+\mathrm{BAT}$ & $\begin{array}{l}152 \text { patients } \\
+165 \\
\text { controls }\end{array}$ & $\begin{array}{c}\text { Leukocytes/basophils/SA/paracetamol/ } \\
\text { naproxen/metamizol/diclophenac }\end{array}$ & $65 \%$ & $80 \%$ & - & - \\
\hline Sanz ML & 2005 & $\mathrm{CAST}+\mathrm{BAT}$ & 60 & $\begin{array}{c}\text { Leukocytes/basophils/ASA/paracetamol/ } \\
\text { naproxen/metamizol/diclophenac }\end{array}$ & $73.30 \%$ & $71.40 \%$ & - & - \\
\hline Gamboa P & 2004 & BAT (CD63) & 60 & $\begin{array}{l}\text { Basophils/ SA/paracetamol/naproxen/ } \\
\text { metamizol/diclophenac }\end{array}$ & $63.30 \%$ & $93.30 \%$ & - & - \\
\hline Sanz ML & 2005 & BAT & 60 & $\begin{array}{l}\text { Basophils/paracetamol/naproxen/ } \\
\text { metamizol/diclophenac }\end{array}$ & $66.70 \%$ & $93.30 \%$ & - & - \\
\hline \multirow[t]{3}{*}{ Celik G } & 2009 & BAT (CD63) & 10 & Basophils & $30 \%$ & $40 \%$ & - & \\
\hline & & BAT (CD203) & 10 & Basophils & $70 \%$ & $45 \%$ & & \\
\hline & & BAT (CD69) & 10 & Basophils & $80 \%$ & $34 \%$ & & \\
\hline \multirow[t]{2}{*}{ BavbekS } & 2009 & BAT (CD63) & 18 & Basophils/ASA, diclophenac & $16.70 \%$ & $91.70 \%$ & - & - \\
\hline & & BAT (CD203) & & Basophils/ASA, diclophenac & $22 \%$ & $100 \%$ & - & - \\
\hline
\end{tabular}


asthmatics was observed in most studies, not allowing for using a single urine $\mathrm{LTE}_{4}$ measurement to predict ASA-sensitivity [91-93].

\section{Eicosanoid Profile in Exhaled Breath Condensates (EBC)}

Sanak et al. proposed measuring a set of 19 eicosanoids in EBC by complementary high-performance liquid chromatography and/or gas chromatography-mass spectrometry to distinguish ASA-tolerant from ASAsensitive asthmatics [94]. The eicosanoid profiling in EBC allowed for $92 \%$ correct classification of aspirinintolerant subjects. The practical use of eicosanoids measurements in EBC to diagnosis of CRS with ASAsensitivity is to be assessed.

\section{Genetic Determinants of NSAIDs Hypersensitivity Several} genes have been associated with aspirin hypersensitivity - most are related to arachidonate metabolism or inflammatory pathways $[47,95]$. HLA-DPB $1 * 0301$ allel has been associated not only with aspirinhypersensitivity but also with higher prevalence of CRS in NERD patients [96-98]. A genome-wide association study documented an increased risk for developing aspirin hypersensitivity in adult patients and two SNPs located on chromosome 6, and one of them (rs3128965) was identified as a genetic marker for NERD [99].

\section{Conclusion}

Hypersensitivity to aspirin and other NSAIDs is a hallmark of severe chronic upper and lower airway disease, thus should be suspected and carefully diagnosed in patients with CRS. Oral aspirin challenge remains a gold standard for diagnosing aspirin sensitivity; however, intranasal challenge with soluble form of aspirin may be a diagnostic alternative. Phenotyping of NERD allows to recommend well-tolerated NSAID, if analgesic and anti-inflammatory therapy is need. For some patients with confirmed hypersensitivity to NSAIDs, aspirin after desensitization may be a valuable option for management of CRS. Further work is necessary to understand the pathomechanism of this syndrome and to improve the diagnosis of NERD.

\section{Compliance with Ethics Guidelines}

Conflict of Interest The authors declare that they have no competing interests.

Human and Animal Rights and Informed Consent This article does not contain any studies with human or animal subjects performed by any of the authors.
Open Access This article is distributed under the terms of the Creative Commons Attribution 4.0 International License (http:// creativecommons.org/licenses/by/4.0/), which permits unrestricted use, distribution, and reproduction in any medium, provided you give appropriate credit to the original author(s) and the source, provide a link to the Creative Commons license, and indicate if changes were made.

\section{References}

Papers of particular interest, published recently, have been highlighted as:

- Of importance

1. Kowalski ML, Makowska JS, Blanca M, Bavbek S, Bochenek G, Bousquet $\mathrm{J}$, et al. Hypersensitivity to nonsteroidal antiinflammatory drugs (NSAIDs) - classification, diagnosis and management: review of the EAACI/ENDA(\#) and GA2LEN/HANN A*. Allergy. 2011;66:818-29.

2. Kowalski ML, Asero R, Bavbek S, Blanca M, Blanca-Lopez N, Bochenek G, et al. Classification and practical approach to the diagnosis and management of hypersensitivity to nonsteroidal antiinflammatory drugs. Allergy. 2013;68:1219-32. This is position paper of Drug Allergy section proposing novel classification of NSAIDs hypersensitivity reactions.

3. Rajan JP, Wineinger NE, Stevenson DD, White AA. Prevalence of aspirin-exacerbated respiratory disease among asthmatic patients: A meta-analysis of the literature. J Allergy Clin Immunol. 2015;135: 676-81.

4. Mullol J, Picado C. Rhinosinusitis and nasal polyps in aspirinexacerbated respiratory disease. Immunol Allergy Clin N Am. 2013;33:163-76. This review summarizes management recommended in patients with rhinosinusitis and hypersensitivity to NSAIDs.

5. Casadevall J, Ventura PJ, Mullol J, Picado C. Intranasal challenge with aspirin in the diagnosis of aspirin intolerant asthma: evaluation of nasal response by acoustic rhinometry. Thorax. 2000;55:921-4.

6. Berges-Gimeno MP, Simon RA, Stevenson DD. The natural history and clinical characteristics of aspirin-exacerbated respiratory disease. Ann Allergy Asthma Immunol. 2002;89:474-8.

7. Szczeklik A, Nizankowska E, Duplaga M. Natural history of aspirin-induced asthma. AIANE Investigators. European Network on Aspirin-Induced Asthma. Eur Respir J. 2000;16:432-6.

8. Bavbek S, Dursun B, Dursun E, Korkmaz H, Sertkaya KD. The prevalence of aspirin hypersensitivity in patients with nasal polyposis and contributing factors. Am J Rhinol Allergy. 2011;25:411-5.

9. Awad OG, Lee JH, Fasano MB, Graham SM. Sinonasal outcomes after endoscopic sinus surgery in asthmatic patients with nasal polyps: a difference between aspirin-tolerant and aspirin-induced asthma? Laryngoscope. 2008;118:1282-6.

10. Kowalski ML, Bienkiewicz B, Kordek P. Nasal polyposis in aspirin-hypersensitive patients with asthma (aspirin triad) and aspirin-tolerant patients. Allergy Clin Immunol Int - J World Allergy Org. 2003;6:246-50.

11. Kowalski ML. Aspirin-sensitive rhinosinusitis and asthma. Clin Allergy Immunol. 2007;19:147-75.

12. Lewandowska-Polak A, Jedrzejczak-Czechowicz M, Makowska JS, Jarzebska M, Jankowski A, Kowalski ML. Lack of association between aspirin-triggered 15-hydroxyeicosatetraenoic acid release and mast cell/eosinophil activation in nasal polyps from aspirinsensitive patients. J Investig Allergol Clin Immunol. 2011;21: 507-13. 
13. Szczeklik A, Gryglewski RJ, Czerniawska-Mysik G, Zmuda A. Aspirin-induced asthma. Hypersensitivity to fenoprofen and ibuprofen in relation to their inhibitory action on prostaglandin generation by different microsomal enzymic preparations. J Allergy Clin Immunol. 1976;58:10-8.

14. Szczeklik A, Sanak M. The broken balance in aspirin hypersensitivity. Eur J Pharmacol. 2006;533:145-55.

15. Roca-Ferrer J, Garcia-Garcia FJ, Pereda J, Perez-Gonzalez M, Pujols L, Alobid I, et al. Reduced expression of COXs and production of prostaglandin $\mathrm{E}(2)$ in patients with nasal polyps with or without aspirin-intolerant asthma. J Allergy Clin Immunol. 2011;128:66-72 e1. The study compares expression of COX-1, COX-2 and expression of prostaglandin $E$ receptors on fibroblast from nasal polyps of aspirin tolerant and hypersensitive patients.

16. Varga EM, Jacobson MR, Masuyama K, Rak S, Till SJ, Darby Y, et al. Inflammatory cell populations and cytokine mRNA expression in the nasal mucosa in aspirin-sensitive rhinitis. Eur Respir J. 1999;14:610-5.

17. Picado C. Mechanisms of aspirin sensitivity. Curr Allergy Asthma Rep. 2006;6:198-202.

18. Kowalski ML, Sliwinska-Kowalska M, Igarashi Y, White MV, Wojciechowska B, Brayton P, et al. Nasal secretions in response to acetylsalicylic acid. J Allergy Clin Immunol. 1993;91:580-98.

19. Kowalski ML, Pawliczak R, Wozniak J, Siuda K, Poniatowska M, Iwaszkiewicz J, et al. Differential metabolism of arachidonic acid in nasal polyp epithelial cells cultured from aspirin-sensitive and aspirin-tolerant patients. Am J Respir Crit Care Med. 2000;161: 391-8.

20. Kowalski ML, Ptasinska A, Bienkiewicz B, Pawliczak R, DuBuske L. Differential effects of aspirin and misoprostol on 15hydroxyeicosatetraenoic acid generation by leukocytes from aspirin-sensitive asthmatic patients. J Allergy Clin Immunol. 2003; 112:505-12.

21. Kowalski ML, Borowiec M, Kurowski M, Pawliczak R. Alternative splicing of cyclooxygenase-1 gene: altered expression in leucocytes from patients with bronchial asthma and association with aspirin-induced 15-HETE release. Allergy. 2007;62:628-34.

22. Cahill KN, Bensko JC, Boyce JA, Laidlaw TM. Prostaglandin $\mathrm{D}(2)$ : a dominant mediator of aspirin-exacerbated respiratory disease. J Allergy Clin Immunol. 2015;135:245-52.

23. Laidlaw TM, Cutler AJ, Kidder MS, Liu T, Cardet JC, Chhay H, et al. Prostaglandin E2 resistance in granulocytes from patients with aspirin-exacerbated respiratory disease. J Allergy Clin Immunol. 2014;133:1692-701 e3. Study described impaired granulocyte function in AERD patients, which can lead to dysregulated control of 5-lipooxygenase by PGE2.

24. Pods R, Ross D, van Hulst S, Rudack C, Maune S. RANTES, eotaxin and eotaxin-2 expression and production in patients with aspirin triad. Allergy. 2003;58:1165-70.

25. Kowalski ML, Grzegorczyk J, Pawliczak R, Kornatowski T, Wagrowska-Danilewicz M, Danilewicz M. Decreased apoptosis and distinct profile of infiltrating cells in the nasal polyps of patients with aspirin hypersensitivity. Allergy. 2002;57:493-500.

26. de Borja Callejas F, Picado C, Martinez-Anton A, Alobid I, Pujols L, Valero A, et al. Differential expression of remodeling markers by tissue structure in nasal polyposis. Am J Rhinol Allergy. 2013;27: e69-74.

27. Steinke JW, Liu L, Huyett P, Negri J, Payne SC, Borish L. Prominent role of IFN-gamma in patients with aspirinexacerbated respiratory disease. J Allergy Clin Immunol. 2013;132:856-65 e1-3.

28. Kowalski ML, Lewandowska-Polak A, Wozniak J, Ptasinska A, Jankowski A, Wagrowska-Danilewicz M, et al. Association of stem cell factor expression in nasal polyp epithelial cells with aspirin sensitivity and asthma. Allergy. 2005;60:631-7.
29. Pawankar R, Lee KH, Nonaka M, Takizawa R. Role of mast cells and basophils in chronic rhinosinusitis. Clin Allergy Immunol. 2007;20:93-101.

30. Bochenek G, Nagraba K, Nizankowska E, Szczeklik A. A controlled study of 9alpha,11beta-PGF2 (a prostaglandin D2 metabolite) in plasma and urine of patients with bronchial asthma and healthy controls after aspirin challenge. J Allergy Clin Immunol. 2003;111:743-9.

31. Adamusiak AM, Stasikowska-Kanicka O, Lewandowska-Polak A, Danilewicz M, Wagrowska-Danilewicz M, Jankowski A, et al. Expression of arachidonate metabolism enzymes and receptors in nasal polyps of aspirin-hypersensitive asthmatics. Int Arch Allergy Immunol. 2012;157:354-62.

32. Nasser SM, Pfister R, Christie PE, Sousa AR, Barker J, SchmitzSchumann M, et al. Inflammatory cell populations in bronchial biopsies from aspirin-sensitive asthmatic subjects. Am J Respir Crit Care Med. 1996;153:90-6.

33. Picado C, Fernandez-Morata JC, Juan M, Roca-Ferrer J, Fuentes $\mathrm{M}$, Xaubet A, et al. Cyclooxygenase-2 mRNA is downexpressed in nasal polyps from aspirin-sensitive asthmatics. Am J Respir Crit Care Med. 1999;160:291-6.

34. Pujols L, Mullol J, Alobid I, Roca-Ferrer J, Xaubet A, Picado C. Dynamics of COX-2 in nasal mucosa and nasal polyps from aspirin-tolerant and aspirin-intolerant patients with asthma. $\mathrm{J}$ Allergy Clin Immunol. 2004;114:814-9.

35. Pierzchalska M, Szabo Z, Sanak M, Soja J, Szczeklik A. Deficient prostaglandin E2 production by bronchial fibroblasts of asthmatic patients, with special reference to aspirin-induced asthma. J Allergy Clin Immunol. 2003;111:1041-8.

36. Roca-Ferrer J, Perez-Gonzalez M, Garcia-Garcia FJ, Pereda J, Pujols L, Alobid I, et al. Low prostaglandin E2 and cyclooxygenase expression in nasal mucosa fibroblasts of aspirin-intolerant asthmatics. Respirology. 2013;18:711-7.

37. Ying S, Meng Q, Scadding G, Parikh A, Corrigan CJ, Lee TH. Aspirin-sensitive rhinosinusitis is associated with reduced Eprostanoid 2 receptor expression on nasal mucosal inflammatory cells. J Allergy Clin Immunol. 2006;117:312-8.

38. Corrigan CJ, Napoli RL, Meng Q, Fang C, Wu H, Tochiki K, et al. Reduced expression of the prostaglandin E2 receptor E-prostanoid 2 on bronchial mucosal leukocytes in patients with aspirin-sensitive asthma. J Allergy Clin Immunol. 2012;129:1636-46.

39. Perez-Novo CA, Watelet JB, Claeys C, Van Cauwenberge P, Bachert C. Prostaglandin, leukotriene, and lipoxin balance in chronic rhinosinusitis with and without nasal polyposis. J Allergy Clin Immunol. 2005;115:1189-96.

40. Corrigan C, Mallett K, Ying S, Roberts D, Parikh A, Scadding G, et al. Expression of the cysteinyl leukotriene receptors cysLT(1) and cysLT(2) in aspirin-sensitive and aspirin-tolerant chronic rhinosinusitis. J Allergy Clin Immunol. 2005;115:316-22.

41. Dahlen B, Nizankowska E, Szczeklik A, Zetterstrom O, Bochenek G, Kumlin M, et al. Benefits from adding the 5lipoxygenase inhibitor zileuton to conventional therapy in aspirin-intolerant asthmatics. Am J Respir Crit Care Med. 1998;157:1187-94.

42. Ragab S, Parikh A, Darby YC, Scadding GK. An open audit of montelukast, a leukotriene receptor antagonist, in nasal polyposis associated with asthma. Clin Exp Allergy. 2001;31:1385-91.

43. Pawliczak R, Lewandowska-Polak A, Kowalski ML. Pathogenesis of nasal polyps: an update. Curr Allergy Asthma Rep. 2005;5:46371.

44. Szczeklik A. Aspirin-induced asthma as a viral disease. Clin Allergy. 1988;18:15-20.

45. Perez-Novo CA, Kowalski ML, Kuna P, Ptasinska A, Holtappels G, van Cauwenberge $\mathrm{P}$, et al. Aspirin sensitivity and IgE antibodies to Staphylococcus aureus enterotoxins in nasal polyposis: studies on the relationship. Int Arch Allergy Immunol. 2004;133:255-60. 
46. Suh YJ, Yoon SH, Sampson AP, Kim HJ, Kim SH, Nahm DH, et al. Specific immunoglobulin E for staphylococcal enterotoxins in nasal polyps from patients with aspirin-intolerant asthma. Clin Exp Allergy. 2004;34:1270-5.

47. Kim SH, Sanak M, Park HS. Genetics of hypersensitivity to aspirin and nonsteroidal anti-inflammatory drugs. Immunol Allergy Clin N Am. 2013;33:177-94.

48. Kim JE, Kountakis SE. The prevalence of Samter's triad in patients undergoing functional endoscopic sinus surgery. Ear Nose Throat J. 2007;86:396-9.

49. Fokkens WJ, Lund VJ, Mullol J, Bachert C, Alobid I, Baroody F, et al. EPOS 2012: European position paper on rhinosinusitis and nasal polyps 2012. A summary for otorhinolaryngologists. Rhinology. 2012;50:1-12.

50. Alobid I, Benitez P, Cardelus S, de Borja CF, Lehrer-Coriat E, Pujols L, et al. Oral plus nasal corticosteroids improve smell, nasal congestion, and inflammation in sino-nasal polyposis. Laryngoscope. 2014;124:50-6.

51. Pleskow WW, Stevenson DD, Mathison DA, Simon RA, Schatz M, Zeiger RS. Aspirin-sensitive rhinosinusitis/asthma: spectrum of adverse reactions to aspirin. J Allergy Clin Immunol. 1983;71:574-9.

52. Bochenek G, Nizankowska E, Szczeklik A. The atopy trait in hypersensitivity to nonsteroidal anti-inflammatory drugs. Allergy. 1996;51:16-23.

53. Sanchez-Borges M, Capriles-Hulett A. Atopy is a risk factor for non-steroidal anti-inflammatory drug sensitivity. Ann Allergy Asthma Immunol. 2000;84:101-6.

54. Kalyoncu AF, Karakaya G, Sahin AA, Baris YI. Occurrence of allergic conditions in asthmatics with analgesic intolerance. Allergy. 1999;54:428-35.

55. Kupczyk M, Kuprys I, Gorski P, Kuna P. Aspirin intolerance and allergy to house dust mites: important factors associated with development of severe asthma. Ann Allergy Asthma Immunol. 2004;92:453-8.

56. Stevenson DD, Kowalski ML. An epidemic of over diagnosing drug allergies. Allergy Asthma Proc. 2014;35:92-4. The paper underlines the importance of drug challenges to avoid overdiagnosis of hypersensitivty to NSAIDs and other drugs.

57. Dursun AB, Woessner KA, Simon RA, Karasoy D, Stevenson DD. Predicting outcomes of oral aspirin challenges in patients with asthma, nasal polyps, and chronic sinusitis. Ann Allergy Asthma Immunol. 2008;100:420-5.

58. Nizankowska E, Bestynska-Krypel A, Cmiel A, Szczeklik A. Oral and bronchial provocation tests with aspirin for diagnosis of aspirininduced asthma. Eur Respir J. 2000;15:863-9.

59. Melillo G, Balzano G, Bianco S, Dahlen B, Godard P, Kowalsky ML, et al. Report of the INTERASMA Working Group on Standardization of Inhalation Provocation Tests in Aspirininduced Asthma. Oral and inhalation provocation tests for the diagnosis of aspirin-induced asthma. Allergy. 2001;56:899-911.

60. Stevenson DD. Approach to the patient with a history of adverse reactions to aspirin or NSAIDs: diagnosis and treatment. Allergy Asthma Proc. 2000;21:25-31.

61. Cormican LJ, Farooque S, Altmann DR, Lee TH. Improvements in an oral aspirin challenge protocol for the diagnosis of aspirin hypersensitivity. Clin Exp Allergy. 2005;35:717-22.

62. Macy E, Bernstein JA, Castells MC, Gawchik SM, Lee TH, Settipane RA, et al. Aspirin challenge and desensitization for aspirin-exacerbated respiratory disease: a practice paper. Ann Allergy Asthma Immunol. 2007;98:172-4.

63. Nizankowska-Mogilnicka E, Bochenek G, Mastalerz L, Swierczynska M, Picado C, Scadding G, et al. EAACI/GA2LEN guideline: aspirin provocation tests for diagnosis of aspirin hypersensitivity. Allergy. 2007;62:1111-8.

64. Szmidt M, Grzelewska-Rzymowska I, Kowalski ML, Rozniecki J. Tolerance to acetylsalicylic acid (ASA) induced in ASA-sensitive asthmatics does not depend on initial adverse reaction. Allergy. 1987;42:182-5.

65. Stevenson DD, Simon RA, Mathison DA, Christiansen SC. Montelukast is only partially effective in inhibiting aspirin responses in aspirin-sensitive asthmatics. Ann Allergy Asthma Immunol. 2000;85:477-82.

66. Berges-Gimeno MP, Simon RA, Stevenson DD. The effect of leukotriene-modifier drugs on aspirin-induced asthma and rhinitis reactions. Clin Exp Allergy. 2002;32:1491-6.

67. White A, Ludington E, Mehra P, Stevenson DD, Simon RA. Effect of leukotriene modifier drugs on the safety of oral aspirin challenges. Ann Allergy Asthma Immunol. 2006;97:688-93.

68. Milewski M, Mastalerz L, Nizankowska E, Szczeklik A. Nasal provocation test with lysine-aspirin for diagnosis of aspirinsensitive asthma. J Allergy Clin Immunol. 1998;101:581-6.

69. Alonso-Llamazares A, Martinez-Cocera C, Dominguez-Ortega J, Robledo-Echarren T, Cimarra-Alvarez M, Mesa del Castillo M. Nasal provocation test (NPT) with aspirin: a sensitive and safe method to diagnose aspirin-induced asthma (AIA). Allergy. 2002;57:632-5.

70. Pawlowicz A, Williams WR, Davies BH. Inhalation and nasal challenge in the diagnosis of aspirin-induced asthma. Allergy. 1991;46: 405-9.

71. Wellbrock M, Mertens J, Cornelius M, Brasch J. Intranasal provocation with lysine acetylsalicylic acid. HNO. 1993;41:577-81.

72. Patriarca G, Nucera E, DiRienzo V, Schiavino D, Pellegrino S, Fais G. Nasal provocation test with lysine acetylsalicylate in aspirinsensitive patients. Ann Allergy. 1991;67:60-2.

73. Miller B, Mirakian R, Gane S, Larco J, Sannah AA, Darby Y, et al. Nasal lysine aspirin challenge in the diagnosis of aspirin - exacerbated respiratory disease: asthma and rhinitis. Clin Exp Allergy. 2013;43:874-80.

74. Munoz-Cano R, Bartra J, Sanchez-Lopez J, Picado C, Bissinger I, Valero A. Acoustic rhinometry and aspirin nasal challenge in the diagnosis of aspirin-intolerant asthma: clinical finding and safety aspects. Int Arch Allergy Immunol. 2013;160:307-12. Authors provide data on clinical safety of nasal challenge test with aspirin, which can be used even in patients with severe asthma.

75. - Wismol P, Putivoranat P, Buranapraditkun S, Pinnobphun P, Ruxrungtham K, Klaewsongkram J. The values of nasal provocation test and basophil activation test in the different patterns of ASA/NSAID hypersensitivity. Allergol Immunopathol (Madr). 2012;40:156-63.

76. Celikel S, Stevenson D, Erkorkmaz U, White AA. Use of nasal inspiratory flow rates in the measurement of aspirin-induced respiratory reactions. Ann Allergy Asthma Immunol. 2013;111:252-5.

77. Kupczyk M, Kuprys-Lipinska I, Bochenska-Marciniak M, Kuna P. Acoustic rhinometry in the evaluation of intranasal aspirin challenge. Pneumonol Alergol Pol. 2010;78:103-11.

78. Lee DK, Haggart K, Lipworth BJ. Reproducibility of response to nasal lysine-aspirin challenge in patients with aspirin-induced asthma. Ann Allergy Asthma Immunol. 2004;93:185-8.

79. Celik G, Bavbek S, Misirligil Z, Melli M. Release of cysteinyl leukotrienes with aspirin stimulation and the effect of prostaglandin $\mathrm{E}(2)$ on this release from peripheral blood leucocytes in aspirininduced asthmatic patients. Clin Exp Allergy. 2001;31:1615-22.

80. May A, Weber A, Gall H, Kaufmann R, Zollner TM. Means of increasing sensitivity of an in vitro diagnostic test for aspirin intolerance. Clin Exp Allergy. 1999;29:1402-11.

81. Sanz ML, Gamboa P, de Weck AL. A new combined test with flowcytometric basophil activation and determination of sulfidoleukotrienes is useful for in vitro diagnosis of hypersensitivity to aspirin and other nonsteroidal anti-inflammatory drugs. Int Arch Allergy Immunol. 2005;136:58-72.

82. Abrahamsen O, Haas H, Schreiber J, Schlaak M. Differential mediator release from basophils of allergic and non-allergic asthmatic 
patients after stimulation with anti-IgE and C5a. Clin Exp Allergy. 2001;31:368-78.

83. Pierzchalska M, Mastalerz L, Sanak M, Zazula M, Szczeklik A. A moderate and unspecific release of cysteinyl leukotrienes by aspirin from peripheral blood leucocytes precludes its value for aspirin sensitivity testing in asthma. Clin Exp Allergy. 2000;30:1785-91.

84. Gray PA, Warner TD, Vojnovic I, Del Soldato P, Parikh A, Scadding GK, et al. Effects of non-steroidal anti-inflammatory drugs on cyclo-oxygenase and lipoxygenase activity in whole blood from aspirin-sensitive asthmatics vs healthy donors. Br J Pharmacol. 2002;137:1031-8.

85. Erdmann SM, Ventocilla S, Moll-Slodowy S, Sauer I, Merk HF. Basophil activation tests in the diagnosis of drug reactions. Hautarzt. 2005;56:38-43.

86. Celik GE, Schroeder JT, Hamilton RG, Saini SS, Adkinson NF. Effect of in vitro aspirin stimulation on basophils in patients with aspirin-exacerbated respiratory disease. Clin Exp Allergy. 2009;39: 1522-31.

87. Bavbek S, Ikinciogullari A, Dursun AB, Guloglu D, Arikan M, Elhan AH, et al. Upregulation of CD63 or CD203c alone or in combination is not sensitive in the diagnosis of nonsteroidal antiinflammatory drug intolerance. Int Arch Allergy Immunol. 2009; 150:261-70.

88. Kowalski ML, Ptasinska A, Jedrzejczak M, Bienkiewicz B, Cieslak M, Grzegorczyk J, et al. Aspirin-triggered 15-HETE generation in peripheral blood leukocytes is a specific and sensitive AspirinSensitive Patients Identification Test (ASPITest). Allergy. 2005;60:1139-45.

89. Korosec P, Tisler U, Bajrovic N, Silar M, Mrhar A, Kosnik M. Acetylsalicylic acid-triggered 15-HETE generation by peripheral leukocytes for identifying ASA sensitivity. Respir Med. 2011;105 Suppl 1:S81-3.

90. James A, Daham K, Backman L, Brunnstrom A, Tingvall T, Kumlin M, et al. The influence of aspirin on release of eoxin C4, leukotriene $\mathrm{C} 4$ and 15-HETE, in eosinophilic granulocytes isolated from patients with asthma. Int Arch Allergy Immunol. 2013;162: 135-42.
91. Higashi N, Taniguchi M, Mita H, Osame M, Akiyama K. A comparative study of eicosanoid concentrations in sputum and urine in patients with aspirin-intolerant asthma. Clin Exp Allergy. 2002;32: 1484-90.

92. Misso NL, Aggarwal S, Phelps S, Beard R, Thompson PJ. Urinary leukotriene $\mathrm{E} 4$ and 9 alpha, 11 beta-prostaglandin $\mathrm{F}$ concentrations in mild, moderate and severe asthma, and in healthy subjects. Clin Exp Allergy. 2004;34:624-31.

93. Higashi N, Taniguchi M, Mita H, Kawagishi Y, Ishii T, Higashi A, et al. Clinical features of asthmatic patients with increased urinary leukotriene E4 excretion (hyperleukotrienuria): Involvement of chronic hyperplastic rhinosinusitis with nasal polyposis. J Allergy Clin Immunol. 2004;113:277-83.

94. Sanak M, Gielicz A, Bochenek G, Kaszuba M, NizankowskaMogilnicka E, Szczeklik A. Targeted eicosanoid lipidomics of exhaled breath condensate provide a distinct pattern in the aspirinintolerant asthma phenotype. J Allergy Clin Immunol. 2011;127: 1141-7.

95. Park SM, Park JS, Park HS, Park CS. Unraveling the genetic basis of aspirin hypersensitivity in asthma beyond arachidonate pathways. Allergy Asthma Immunol Res. 2013;5:25876.

96. Dekker JW, Nizankowska E, Schmitz-Schumann M, Pile K, Bochenek G, Dyczek A, et al. Aspirin-induced asthma and HLADRB1 and HLA-DPB1 genotypes. Clin Exp Allergy. 1997;27: 574-7.

97. Choi JH, Lee KW, Oh HB, Lee KJ, Suh YJ, Park CS, et al. HLA association in aspirin-intolerant asthma: DPB $1 * 0301$ as a strong marker in a Korean population. J Allergy Clin Immunol. 2004;113:562-4.

98. Park HS, Kim SH, Sampson AP, Lee KW, Park CS. The HLADPB $1 * 0301$ marker might predict the requirement for leukotriene receptor antagonist in patients with aspirin-intolerant asthma. J Allergy Clin Immunol. 2004;114:688-9.

99. Kim SH, Cho BY, Choi H, Shin ES, Ye YM, Lee JE, et al. The SNP rs3128965 of HLA-DPB1 as a genetic marker of the AERD phenotype. PLoS One. 2014;9, e111220. 